\title{
MYTHOLINGUISTIC ANALYSIS OF DIFFERENT TOPONYMS IN KARAKALPAK EPICS
}

\author{
Khojaakhmed Yelbayevich Tolibayev
}

Doctoral Student, Karakalpak State University Nukus, Republic Of Uzbekistan

ABSTRACT

This article provides information on the type of folk descriptive analysis of the analysis of toponyms, the origin of some toponyms in Karakalpak folk tales, toponymic legends and myths associated with them. Thus, theoretical materials on the mytholinguistics formed in linguistics and its object of study are presented. Legends and myths in Karakalpak folklore related to the origin of some toponyms in Karakalpak epics are analyzed. The peculiarities of the population's naming of geographical objects are studied. Toponyms in Karakalpak epics such as "Adak kala", "Konyrat", "Khorezm", "Chimbai", "Bagdad", "Nur ata" are analyzed. It was noted that the naming of geographical objects by the Karakalpak people is often associated with human names.

KEYWORDS: - Research methods, toponyms, Karakalpak epics, legends, myths, legends, onomastic mytholinguistics.

\section{INTRODUCTION}

Both historical and scientific sources confirm that the culture, art, literature and language of the Karakalpak people have risen to a higher level in folklore. In the development of both Karakalpak literature and the literary language, the language of folklore has its own significance. Because, as professor D.S.Nasirov wrote "the epic works of the Karakalpak people are only studied from the point of view of literary science, in other words, comparing the linguistic facts preserved in these monuments with modern linguistic data is of great value for the history of language and and in the future should be the object of special research for linguists" [1 , 221].

The origin of toponyms in Karakalpak epics dates back to ancient times. The history of the people, its culture and customs are reflected in these toponyms. The way of life of the Karakalpak people - livestock, farming, craftsmanship, historical processes - moving from one place to another influenced the Karakalpak toponymy. The finding and settlement on the land, which is convenient for the people, plays an important role. So, in the basis of the view point to settled place, and its features the phenomenon of naming is occurred. These phenomenons, in turn, influenced the origin of toponyms.

The people had certain bases on naming the land and water objects. They meet in ancient religious traditions - beliefs such as animism, totemism, Zoroastrianism, and then Islamic religions. These beliefs have gradually developed and have led to the enlightenment of the people's worldview. The ancient views of the people are especially reflected in the mythological form.

Usually, such mythological toponyms serve as 
CURRENT RESEARCH JOURNAL OF PHILOLOGICAL SCIENCES 2(10): 06-

14, October 2021

DOI: https://doi.org/10.37547/philological-crjps-02-10-02

ISSN 2767-3758

(C)2021 Master Journals

Crossref do

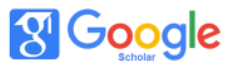

Accepted08th October, 2021 \& Published $13^{\text {th }}$ October, 2021

assistant in performing difficult tasks, adding power of the main hero of the epic, and emergence of a special power.

\section{Method AND METhODOLOGY}

Scientists studying land and water toponyms use etymological, formative and word-formation (structural-grammatical) analyzes of linguistic methods in the study of toponyms as words. Wellknown toponymist A.V. Superanskaya shows nineteen different methods and techniques of analysis of onomastic materials [2, p. 198-214]. Uzbek toponymist T. Enazarov demonstrates seven different methods of analysis: 1 ) linguistic analysis and terminology; 2) historical analysis and terms; 3) geographical analysis and names of geographical objects; 4) geological analysis and names of geological objects; 5) ethnographic analysis and proper terms; 6) psychological analysis and terms; 7) philosophical analysis and proper names. And the linguistic analysis has the types of descriptive analysis, folk descriptive analysis and etymological analysis [3, p. 60-64].

\section{Research of the problem}

One of the well-known toponymists, V.A. Nikonov writes about the problem of determining the origin of toponyms: "No one knows and will never know" the earliest toponym ". This is not the weakness of science. Not so. This is a process that has lasted for thousands of years, not because they started from the second term, but because the myths illuminate the formation of toponymy as someone's creation. Initially, they did not develop the terms of proper and common. ... Their separation took place later. However, it took place in ancient times, which were not open to toponymic research "[4, p.28].

According to scientists, toponymic legends and myths are not scientifically forbidden, so it is impossible to say that the toponym really originated from the individuals, events and hadiths in their content. However, it is possible to determine the basis for the origin of the toponym through folk etymology. For example, the origin of the toponym Chimbai is mentioned in toponymic legends in connection with the name of a person, and historians and linguists have supported this. The same can be said about the legend "Guldirsin".

The following opinion of the scientist E.F. Kovlakas, who studied the toponymic picture of the world from the lexical-pragmatic and ethnocultural aspects, is noteworthy: "Reconsideration of real objects and their reflection in toponyms, in the formation of ethnic beliefs, ethnic perception of the world and re-think in its preservation in human memory plays an important role. These qualities of perception and understanding of ethnic views reflected in toponymic myths are an integral part of the memory, serves as a retail, subjective or relevant cognitive worldview about the real world of the past, reflecting this or that historical event.[5,p 42].

Thus, a new branch of onomastics - onomastic mytholinguistics - was created. The object of its research is toponymic synopsis, toponymic legends, toponymic legends and historical events. It is a new branch of onomastics that emerged at the syncretic intersection of folklore, mythology, linguistics, ethnology and psychology.

In the study of Uzbek folklore, U.F. Sattarov studied the toponymic legends of the Uzbek people [6]. There are researches of A.Baymiradov in Turkmen folklore [7, p. 25]. He divided toponymic legends into 2 groups: 1) legends about historical monuments; 2) legends about the origin of the name of certain objects.

In his study of Azerbaijani folk legends, scientist T. 
CURRENT RESEARCH JOURNAL OF PHILOLOGICAL SCIENCES 2(10): 06-

14, October 2021

DOI: https://doi.org/10.37547/philological-crjps-02-10-02

ISSN 2767-3758

(C)2021 Master Journals

Crossref do

8 Google

Accepted08 ${ }^{\text {th }}$ October, 2021 \& Published $13^{\text {th }}$ October, 2021

Farzaliyev classified them as follows:

1) cosmogonic legends,

2) legends related to the geographical and toponymic terms,

3) catastrophic motive myths,

4) legends related to the earth's fauna,

5) legends related to the earth's flora.

6) anthropomorphic myths,

7) myths related to the monuments of material culture,

8) myths related to mythical, semi-mythical and historical figures,

9) myths related to folk art [8, p. 32-38].

S.M. Giylajetdinov, who studied the legends in Tatar folklore, divides them into historical legends, legends about the origin of villages, toponymic legends, life legends [9, p. 13].

Uzbek scientist U. Sattarov proposes to classify toponymic legends in order to determine the history of the formation of the plot of legends, i.e. the stages of chronological development. "Because, the plot system of toponymic legends is, of course, a product of a certain historical period. It was realized as a result of the gradual development of the epic consciousness of the people during a certain historical and folklore process [6, p. 69].

Thus, it is difficult to classify folk toponymic myths and legends into certain groups. However, we believe that the above problem can be solved by looking at the historical figures (kings, khans, celebrities, etc.) that are found in the ancient written monuments, written records, toponymic legends and myths related to the history of the people. According to the origin of toponyms in Karakalpak epics, the historical chronology of legends and myths is also important in the chronology of epics.

Therefore, as we have seen above, in the folklore of the Turkic peoples there are different classifications in the division of toponymic legends, myths and legends into certain groups.

In onomastics there is a way to classify toponyms according to the properties of the object. In connection with this, i.e. on the basis of theoretical views on onomastics, toponymic legends, myths and legends in folklore can be classified as follows: 1) oikonomic legends, 2) hydronymic legends, 3) oronymic legends, 4) necronymic legends.

Therefore, we see that the views of our people on the origin of toponyms are reflected in the Karakalpak toponymic legends.

Toponymist .A. Nikonov on the importance of linguistics in the etymological study of toponyms wrote: It is impossible to understand the place of suffixes which play main role in the definition of the laws of modern toponymy, in the formation of geographical terms without the methods of linguistics [10], E.M. Murzaev: The etymological study of toponyms should be based on all the data and achievements of linguistics $[11,10]$, - seems to be a continuation of the above. The Uzbek toponymist S. Korayev commented on the peculiarities of the etymological study of toponyms: The meaning of these terms, no matter how many opinions have been expressed as to which language they belong to, cannot be said to be definitive. There is a view that the number of opinions expressed about the etymology of toponyms is not proportional to their degree of accuracy. This means that as the number of opinions increases, the degree of clarity of etymology increases" [12, 5152].

From this point of view, in this article we have agreed to talk about the some toponyms and toponymic legends and myths related to them that are found in the language of Karakalpak folk tales. 
CURRENT RESEARCH JOURNAL OF PHILOLOGICAL SCIENCES 2(10): 06-

14, October 2021

DOI: https://doi.org/10.37547/philological-crjps-02-10-02

ISSN 2767-3758

(C)2021 Master Journals

Crossref do

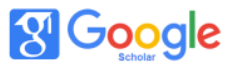

Accepted08 ${ }^{\text {th }}$ October, 2021 \& Published $13^{\text {th }}$ October, 2021

\section{MaIn PART}

Adak. The toponym "Adak" is found in the Karakalpak version of the epic "Gulistan" performed by Kiyas Zhyrau:

Aidar khan degen khan otti,

Karakalpaktyn khalkynda,

Kaidan bolar? deseniz,

Adak degen shahari,

Amiw boyi Aralda. Aidar Khan passed,

In the people of Karakalpak,

If you ask where's he from?

The city of Adak, on the Aral Sea,

Along the Amu Darya.

Many scholars point out that the etymology of the word "adaq" is related to the word "adaq" (ayaq (foot), which means a human organ in the ancient Turkic period. This word is found in the Altaic languages, as well as in the Turkic languages in various phonetic variants. For example, from the family of Altai language in Mongolian "adaq", and in Buryat "adg" mean "foot". Also, the word "adg" in the Kalmyk language means "the bottom of the river". We can see that Professor Sh. Abdinazimov gave a more detailed explanation of the etymology of this word: "In the intervocal position, in places where the sonoric "y" is used in the modern Karakalpak language, the use of the vowel " $d$ " in the Old Turkic period has been determined by turkologists. It can be seen that in the modern Karakalpak language the same old form is preserved in the composition of some words. For example, the word "adaq arba". From the point of view of our modern language, the name of this product means "ayaq arba (foot stroller)", which helps babies to walk. However, in the word "adaq" the old form is preserved "[13, 149]. Toponymist K. Abdimuratov considered this toponym as one of the oldest cities and gave the following information about it: "This word can be an old form of the word "Ayaq (Foot)" in Turkish. So, adak, ayaq are meaningful word that are related to each other. Due to this, the notion that Adak is a city in the place of pouring of river into the sea, at the end of the river is more realistic" $[14,16]$. Toponymist E.M. Murzaev learns the word "Adak" as one of the geomorphological terms that characterizes the form and type of relief. The scientist said about this: "ada / ata / adag / atau / atrau - 'islands '. In the toponymy: Adagum in Krasnodar Krai, island Buyukada in the Marble Sea, the Black Sea resort of Adler (from ada +- lar - an indicator of the number), the sands of Saryesikatyrau in Kazakhstan "[15, 106], - he wrote. There is information that the city of Adak was under the Aral Sea, and the city of Adak was submerged and the Aral Sea was formed. H. Hasanov's dictionary informs about the existence of the toponym Adak in two places: "1) a city in the foothills of the Amu Darya, near the Sarykamys ravine; 2) One of the names of the city of Andijan "[16, 59]. The dictionary of Z. Dusimov and $H$. Egamov contains similar information about this toponym: This city was located on the banks of the ancient Amu Darya, near the Sarykamysh ravine $[17,110]$.As a geographical name, Adaq is found in several places in Turkmenistan and Uzbekistan. One tribe of Turkmens is called Adaqlykhyzyr. In the dictionary of Mahmud Kashgari it is also found in azaq form $[18,91]$.

Scientist K. Mambetov says that the bottom of the Aral Sea used to be the "Land of the Adaqlar" and quotes an interesting legend about the toponym: "Once upon a time, the Aral Sea was replaced by a ruthless king named Fasyl Khan. When Fasil Khan acted in a way that did not meet the norms of humanity, he was cursed and his people were flooded. That is, two rivers flowing into the Ashtarkhan (Caspian) Sea stopped there and formed the Aral Sea. After that, the people of Baisyn moved to Khorezm and formed a kingdom called Urgench "[19, 16-17]. 
CURRENT RESEARCH JOURNAL OF PHILOLOGICAL SCIENCES 2(10): 06-

14, October 2021

DOI: https://doi.org/10.37547/philological-crjps-02-10-02

ISSN 2767-3758

(C)2021 Master Journals

Crossref do

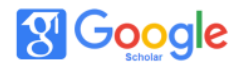

Accepted08th October, 2021 \& Published $13^{\text {th }}$ October, 2021

Qonirat. The legends "Konyrat ataui", "Konyr atly adam" contain information about the origin of the toponym Konyrat. In the legend called "Konyrat ataui" - modern Konyrat was replaced by water, there was an island. When the island was flooded, a konyr (brown) at (horse) and a mare were left. From then on, the place was called Konyrat. Then people started coming here.

And in the legend of the "Konyr atli adam (Man on a Brown Horse)" the origin of this toponym is connected with the horse of a man. In the old days, there was a famine in the area of present-day Konyrat, then a man on a brown horse appeared and brought a bag of grain every day and distributed it to the people. The people survived the famine because of that man with brown horse. It is said that then it was called "Konyrat".

In the language of Karakalpak epics can be found in the following examples:

Shiqqani Qonyrat qalasi,

Isinin joqdur shalasi. The origin is the city of Konyrat,

There's no lack in his work.

(Epic "Alpamys" Esemurat zhyrau's variant)

Atin Khorezm deydiler,

Tuwgan elim Qonyrat. His name is Khorezm,

My native land is Konyrat.

(Epic "Er Sayim". Kurbaybay zhyrau's variant)

There are several probabilities about the origin of the term Konyrat. S. Abramzon connects the origin of this term with the appearance of brown horses on the troops of this tribe $[20,129]$. Kazakh scientist A. Abdurakhmanov says that the toponym Konyrat in Kazakhstan came from the ethnonym, the ethnonym itself came in the basis of knowing the brown horse as totem. Such folk etymology can be applied to the Karakalpak ethnonym.

However, most scholars do not agree with the above etymology about the term Konyrat. Toponymist T. Nafasov connects the etymology of the word konyrat with the Mongolian word kerey (garga). According to him, the ethnotoponym Konyrat has no connection with the color word brown. He explains this word as a combination of the Mongolian words hun kerey (qara garga (black crow)): hun + kerey $+\mathrm{t}>$ hunkereit> hunkirat> konyrat [21, 261-262]. D.S. Nasyrov connects this word with the words "kangar, hun, kanly" and shows that the -at component means plural.

Chimbai. There are legends "Chimbai", "Uyinen kuwilganlar (Expelled from home)"associated with the term "Chimbai". The legend "Uyinen kuwilganlar" tells about the names Daukara and Chimbai. It is said that they were both children of the same father. The legend "Chimbai" contained similar information. The content of both legends is similar.

In ancient times there was a forest on the land of modern Chimbai. There was a canal in the forest, and people cut from the kegeyler (canyons) along the canal and used for their carts and pulleys. Hence, his name was Kegeyli. A young man named Chimbai came to the forest tormented by poverty and made a living by fishing in the canal. So the people began coming after hearing about that forest, the channel. Then these places begin to develop. Chimbai has a daughter Chomanai, sons Dawkara and Tazgara. Daukara moved with his family to a place where his cattle grazed. His place of residence is called Daukara.

We find this toponym in the following examples:

Eki inisi mal bagip,

Arkasinda Chimbaidin,

Karatup degen makande,

Omar shigip zhur edi.

cattle,

Two brother fed the

Thanks to Chimbai, 
CURRENT RESEARCH JOURNAL OF PHILOLOGICAL SCIENCES 2(10): 06-

14, October 2021

DOI: https://doi.org/10.37547/philological-crjps-02-10-02

ISSN 2767-3758

(C)2021 Master Journals

Crossref do

8 Google

Accepted08 ${ }^{\text {th }}$ October, 2021 \& Published $13^{\text {th }}$ October, 2021

In the place Karatup,

Omar used to go out.

(Epic "Aydos biy". Kiyas zhyrau Kayratdinov)

Bul aytilg'an soz, emes tek sagimga,

Chimbai kalasinin argi zhaginda.

This is not a spoken word, only in mind,

On the other side of Chimbai.

(Epic "Bekimbet bakhi bayazı")

Toponyms of Chimbai region were studied linguistically by G. Abishov [22, 163]. The scientist supports the existence of an anthroponym as a topobasis for the name of the district. Such information can be found in the works of $K$. Abdimuratov, K. Aimbetov and in the materials of the Chimbai People's Museum.

K. Aimbetov gave the following information about the history and origin of the city of Chimbai: Before the appearance of the city of Chimbai, a man named Chinbay lived here. Nomadic peasants come in the winter months, sell their cattle for 3-4 months, and in the summer their grain as food. And when spring comes and summer comes, Chimbai's market closes and trade stops. Later there was a market in both winter and summer, and Chimbai was a large city $[23,258]$.

Khorezm. In connection with the origin of the toponym "Khorezm" in Karakalpak folklore there is a legend "Khorezmshah and Nazlymkhan sulu". Its summary is as follows: In ancient times, the people of Khorezm matured three times and disappeared three times. Because it was swallowed by a dragon. A young man named Khorezm killed that dragon. The people elect him as their khan. Khorezm was a equitable khan for the people and his fame spread to the whole nation. That is, the origin of the Khorezm toponym is connected with the human name. (V. 78, p. 64)

The term "Khorezm" is used in many Karakalpak epics: "Alpamys", "Kyryk Kyz", "Dawletiyarbek", "Er Kosai", "Kyz Paluan", "Gulistan", "Er Ziywar", "Er Saim", "Yusup-Akhmet". , "Haji Gerey", "Otesh batyr". For example, Khorezzmnin patshasi,

Kiyatirgan Babakhan. The king of Khorezm, Babakhan is coming.

(Epic "Alpamys". Kurbanbay zhyrau's variant)

Khorezmde Waysinkhan,

Ashik bolip sirtinan,

Gulayimday suliwga.

In Khorezm Waysynkhan,

Fell in love in absentia,

With beautiful Gulayim.

(Epic "Kyryk kyz". Kiyas zhyrau Kayratdinov's variant)

Most scholars believe that the parts zim and $\mathrm{zm}$ at the end of the word Khorezm are related to the word "zher (earth)". Historian S.P. Tolstov, referring to the ethnonyms Hwarry and Hurrit, defines the "land of Hwarry" [17, 143].

According to the Sogdian scientist M.N. Bogolyubov, Khorezm consists of three components: hu - var (vara) - zim. Var (vara) in the ancient Khorezmian language means "diywal, korgan, kora (wall, castle)", hu - well, so Khorezm means a well-armed land, a land with wonderful fortresses [24, 175].

Baghdad. The area around Baghdad used to be flooded. When the water dried up, two people came and settled down. One of them had no wife. He killed a man who had a wife and took his wife. She bore a son and named Dat. Later, Abdullah Khan learned of the incident from an old woman in that city and hanged the man who had killed his father.

The city was handed over to Dat and the city was renamed Baghdad.

Baǵdad is one of the most common toponyms in the language of Karakalpak epics:

Yalgiz qayda baray, qaysi diyara? 
CURRENT RESEARCH JOURNAL OF PHILOLOGICAL SCIENCES 2(10): 06-

14, October 2021

DOI: https://doi.org/10.37547/philological-crjps-02-10-02

ISSN 2767-3758

(C)2021 Master Journals

Crossref do

81 Google

Accepted08 ${ }^{\text {th }}$ October, 2021 \& Published $13^{\text {th }}$ October, 2021

Bulbuldek etmeyin guli-gulzara,

Yurtidin ayrilgan men bir biyshara,

Bu shahri Bagdada kelgen Garibmen. Where

to go alone, which area?

Flowers bloom before the nightingale,

I lost my homeland, a poor man,

This is a Garib who came to Baghdad. (Epic "Garip Ashik". Kazi Mawlik's variant)

Baghdad is the capital of the Iraq. In 762, the Abbasid caliph Abu Jafar al-Mansur changed the capital from Ctesiphon to Baghdad. This is because name Ctesiphon is Greek.

In addition, there were cities and villages in the name of Baghdad. For example, in the region of Karakalpakstan there was a place with this name.

Such a phenomenon occurs in toponymy. Such toponyms are called migrant toponyms. It depends on political and historical reasons, such as the relocation or colonization of certain members of the population. Also, in other cases, the names of famous cities can be used as names of people in other places.

Now, there are differing views on the etymology of the Baghdad toponym. Some scholars have suggested that the term Baghdad is derived from the Iranian words bagh and dad, meaning "qudaydin inami (god's gift)" [25,38]. That is, in the ancient Iranian languages, phag-bagh is said to mean -god, and the word dad means faith, gift. Others quotes comments that the word bagh in Persian means a place with many fruit trees and fruitless trees, while the word dad in Persian means "justice, complaint"; The term Bagdad means "garden of justice" or "garden of complaint."

Nur Ata. Nur Ata is a sacred place from ancient time. There was a large cemetery called "Karakalpak Cemetery", at that time people used to visit
Turkestan as "Second Mecca", and later visited Nur. In the legend, it is said that the Karakalpak cemetery in Nur Ata has existed for thousands of years.

In the Karakalpak epics we find the following examples:

Arkasinda Nuratanin,

Zhankent penen Saskala. Thanks to Nurata,

Zhankent and Saskala

(Epic "Amanbay batyr". Kiyas zhyrau's variant)

Kim Nuraga qashadi,

Kim zhyraga qashadi. Who runs to Nura,

Who runs to far.

(Epic "Izzet qiz". Bekmurat zhyrau's variant)

Nuranin kara kuminan,

Nogaydin toil zhurtinan,

Kiyatirman men shigip.

Out of the black sands

of Nura,

Out of the land of Nogai,

I'm coming.

(Epic "Edige". Erpolat zhyrau's variant)

The nura component in the toponyms Nura, Nura Kum, Nur Ata is a word typical of the Mongolian language. In the dictionary of E.M. Murzaev it is said that in Mongolian noroh means destruction, collapse [26, 253]. But, U. Koychubaev believes that the word nura means the peak of a mountain, the top of a mountain, and the roots of the words nura and naryn are the same. Uzbek toponymists also connect the origin of the Mongolian words nura, nuru with the words "chain, mountain chain, mountain peak, the upper part of the mountain."

\section{Conclusion}

There are no universal methods and techniques for the study of toponyms. It depends on the object of the research, the nature of the material collected, the purpose and tasks, and requires a personal approach from the researcher. However, 
CURRENT RESEARCH JOURNAL OF PHILOLOGICAL SCIENCES 2(10): 06-

14, October 2021

DOI: https://doi.org/10.37547/philological-crjps-02-10-02

ISSN 2767-3758

(C)2021 Master Journals

Crossref d

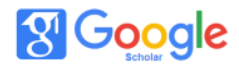

Accepted08th October, 2021 \& Published $13^{\text {th }}$ October, 2021

onomastics shows the methodology, methods and techniques of research of proper terms, aspects of research. In this regard, we also aimed to study the toponyms of Karakalpak epics.

The material of folk etymology is toponymic legends, myths and legends. In them, the origin of a certain toponym is thought by nation and is often associated with people, historical figures or individuals, events and hadiths. Especially when we pay attention to the toponymic legends of Karakalpak folklore, we see that most of them are named after names of men, who inhabited, prospered, or happened historical events related to them.

In common, in the etymological analysis of any toponym, it is required to be considered in connection with the in-depth knowledge of the laws of linguistics, as well as the achievements of sciences such history, ethnography, geography, and others. In this regard, the following opinion of the Turkologist K.M. Musaev on the methodology of etymological research in the science of toponymy is of special attention: "Toponymy is first and foremost a branch of linguistics. However, in the etymological analysis of toponyms, along with linguistics, it is necessary to take into account the history of the population, the geography of the region, as well as the features of the place of native speakers and geographical conditions of the region. Without historical and geographical data, linguistic analysis does not provide a reliable etymology". [27, 72] Toponyms have become a companion of an epic word that contains any property of the land, historical events related to it. Therefore, at the root of the names of land and water is the cultural heritage, which carries many other secrets, related to the past, life, language of the people and others.

\section{REFERENCES}

1. Nasyrov D.S. Stanovlenie karakalpakskogo obshchenarodnogo karakalpakskogo yazyka i ego dialectnaya sistema. - NukusKazan: "Karakalpakstan", 1976. -p. 221

2. Superanskaya A.V. and others. Teoriya va metodika onomasticheskiy issledovaniy. M., Publishing house LCI, 2007. -256 p.

3. Enazarov T. and others. Uzbek nomshunosligi. - Toshkent: Navruz, 2015. $224 \mathrm{p}$.

4. Nikonov V.A. Vvedenie $\mathrm{v}$ toponimiku. $-\mathrm{M}$., Publishing house LKI, 2011. 184 p.

5. Kovlakas E.F Osobennosti formirovaniya toponimicheskoy kartiny mira: lexikopragmaticheskiy i etnokulturniy aspekty: abstr. ... Dr. Sc. philol. sciences. - Krasnodar, 2009 .-- 51 p.

6. Sattarov U. Uzbek khalk rivoyatlari toponymy: diss. Can. philol. sc. - Toshkent, 2001 .- 158 p.

7. Baymiradov A. Turkmenskie narodnie predaniya. AKD. Ashkhabat, 1977. p.25.

8. Farzalijev T. Afsana anlajishi va azarbayjchan afsanalarynyn tasnify // press. AN Azerb. - 1978, No. 1.

9. Tatar halyk izhaty: Rivayatlar ham legendalar. - Kazan, 1987.

10. Nikonov V.A. Geographiya Russkikh suffixov // "Onomastica", coll. 9. - Krakow, 1959.

11. Murzaev E.M. Ocherki toponimiki. Moscow: Mysl', 1974. -p. 10

12. Koraev S. Toponimika. -Tashkent: Publishing House of the National Society of Philosophers of Uzbekistan, 2006.-p. 51-52

13. Abdinazimov Sh. Lingvofolkloristika. Training manual. -Nukus: Bilim, 2018. -p. 149

14. Abdimuratov K. Nege usilay atalgan? (Karakalpakstan toponimikasinin tariykhynan). -Nukus: Karakalpakstan, 1965. -p.16 
CURRENT RESEARCH JOURNAL OF PHILOLOGICAL SCIENCES 2(10): 06-

14, October 2021

DOI: https://doi.org/10.37547/philological-crjps-02-10-02

ISSN 2767-3758

(C)2021 Master Journals

crossref do) 80 Google

Accepted08 ${ }^{\text {th }}$ October, 2021 \& Published $13^{\text {th }}$ October, 2021

15. Murzaev E.M. Tyurkski geografikeskie nazvaniya. - Moscow: Vostochnaya literatura, 1996. -p. 106

16. Hasanov H. Orta Osiyo zhoy nomlari tarikhidan. -Tashkent: FAN, 1965.-p. 59

17. Dusimov Z., Egamov H. Joy nomlarining kiskacha izohli lugati. - Tashkent: Ukituvchi, 1977. -p. 110

18. Koraev S. Geographik nomlar manosini bilasizmi? -Tashkent: Uzbekiston, 1970 .-- p. 91

19. Mambetov K. Karakalpaklar tariykhy. Nukus: Karakalpakstan, 1993. p.16-17

20. Abramzon S.M. K semantike kirgizskikh etnonymov // Sovetskaya Etnographiya. M. -L., 1946, No. 3. -p. 129

21. Nafasov T. Ozbekiston toponymlarining izohli lugati. -T., 1988. -p. 261-262

22. Abishov G.Chimbai toponymlerinin tariykhiy - lingistikalik analizi. Diss. Ph.D. philol.sc - Nukus, 2019.163 p.

23. Aimbetov K. Khalyk danalygy. - Nukus: Karakalpakstan, 1988 .-- p. 258.

24. Koraev S. Ozbekiston viloyatlari toponymlari. P 175.

25. Nikonov V.A. Kratkiy toponimicheskiy slovar'. -M: "Mysl'". 1966 .-- p. 38

26. Murzaev E.M. Slovar narodnykh geographicheskikh terminov. - M .: "Mysl'", 1984.-p. 253

27. Musaev K.M. Lexikologiya tyurkskikh yazikov. -M .: Nauka, 1982. -P.72 